\title{
TINJAUAN HUKUM MENGENAI PENGENAAN UANG WAJIB TAHUNAN TERHADAP PEMILIK SERTIPIKAT HAK MILIK YANG BERADA DIATAS HAK PENGELOLAAN DI KOTA BATAM
}

\author{
Agustianto $^{1}$, Actika $^{2}$
}

\begin{abstract}
Land Rights Certificate in Batam is above the Land Management rights held by the Batam Concession Agency, therefore the types of land rights that can be granted by management rights are Building Rights, Cultivation Rights, and Usage Rights by Government Regulation Number 40 of 1996. Freehold title cannot be above land management rights because they conflict with the original nature of ownership rights. However, a certificate of ownership has been issued that it is above Land Management rights, wherein the certificate of ownership is not subject to annual compulsory money. The research method used in this study is an empirical research method that results from direct interviews with resource persons. Based on the completed research, the conclusions and suggestions of this study are the issuance of a Freehold Title in Batam above the Land Management Right occurred due to an error interpretation that resulted in the issuance of a recommendation letter on Property Rights over the Management Right conducted by the Batam Business Entity Leader beforehand and the imposition of Annual Obligatory Money on Freehold Title holder must not occur, thefore, the consequence violates the law, consequently what must be done is the abolition of Management Rights in the Certificate of Property Rights.
\end{abstract}

Keywords : Management Right, Annual Obligatory Money, Certificate of Ownership

\begin{abstract}
Abstrak
Sertipikat Hak Atas Tanah di Kota Batam seluruhnya berada di atas Hak Pengelolaan Lahan yang dipegang oleh Badan Pengusahaan Batam, sehingga jenis Hak Atas Tanah yang dapat diberikan Hak Pengelolaan adalah Hak Guna Bangunan, Hak Guna Usaha dan Hak Pakai sesuai dengan Peraturan Pemerintah Nomor 40 Tahun 1996. Hak Milik tidak dapat berada di atas Hak Pengelolaan Lahan karena bertentangan dengan sifat asli Hak Milik. Namun faktanya telah terbit Sertipikat Hak Milik yang berada diatas Hak Pengelolaan Lahan, dimana Pemegang Sertipikat Hak Milik tersebut tidak dikenakan Uang Wajib Tahunan. Metode penelitian yang digunakan pada penelitian ini adalah metode penelitian empiris yang memperoleh hasil dari wawancara langsung dengan Narasumber yang berkaitan dengan penelitian ini. Berdasarkan penelitian yang telah dilakukan, kesimpulan serta saran dari penelitian ini adalah, bahwa penerbitan Sertipikat Hak Milik di Kota Batam yang berada di atas Hak Pengelolaan Lahan terjadi karena adanya kesalahan penafsiran yang mengakibatkan dikeluarkan surat
\end{abstract}

\footnotetext{
${ }^{1}$ Dosen Program Sarjana Hukum Universitas Internasional Batam

${ }^{2}$ Mahasiswa Program Sarjana Hukum Universitas Internasional Batam
} 
rekomendasi Hak Milik diatas Hak Pengelolaan yang dilakukan oleh Pempimpin Badan Pengusahaan Batam terdahulu serta pengenaan Uang Wajib Tahunan terhadap pemilik sertipikat Hak Milik tidak boleh terjadi dan akibatnya adalah melanggar hukum, maka dari itu yang harus dilakukan adalah Penghapusan Hak Pengelolaan yang ada di Sertipikat Hak Milik.

Kata Kunci : Hak Pengelolaan, Uang Wajib Tahunan, Sertipikat Hak Milik

\section{A. Latar Belakang}

Pemerintah dari berbagai negara melihat pentingnya tanah bagi manusia sehingga membentuk aturan khusus yang berkaitan dengan tanah. Aturan tersebut dibentuk agar dapat mengatasi segala permasalahan yang muncul akan tanah. Indonesia pada era penjajahan Belanda telah mengenal aturan-aturan tanah yang dibuat oleh Kolonial Belanda.

Indonesia paska kemerdekaannya, mulai menggunakan peraturan tentang pertanahan yang dibawa oleh kolonial Belanda, yang awalnya Indonesia hanya mengenal dan menerapkan hukum adat tentang pertanahan. Dengan begitu terjadi dualisme hukum terhadap aturan pertanahan.

Tahun 1960 dibentuklah Peraturan Dasar Pokok-Pokok Agraria yaitu UndangUndang Nomor 5 tahun 1960 karena Pemerintah menyadari bahwa adanya dualisme hukum serta peraturan hukum Belanda yang dianggap sangat tidak memiliki keterpihakan kepada Masyarakat Indonesia. UUPA mengatur tentang hukum agraria yang mencakup peraturan-peraturan hukum yang terdapat kaitannya dengan pertambangan, air, tanah, perikanan dan ruang angkasa.

Pasal 50 UUPA, dijelaskan bahwa "Ketentuan-ketentuan lebih lanjut mengenai hak milik diatur dengan Undang-undang", akan tetapi Undang-Undang yang terdapat Pasal 50 belum juga tebentuk, maka selama Undang-Undang belum terbentuk, UUPA masih diberlakukan. Meskipun Undang-Undang mengebnai Hak Milik belum juga dibentuk, terdapat beberapa peraturan perundang-undangan yang didalamnya mengatur tentang Hak Milik.

Hak Milik mempunyai jangka waktu yang berbeda dengan Hak Atas Tanah lainnya, yaitu tidak terbatas, sedangkan Hak Atas Tanah lainnya memiliki Jangka waktu yang dibatasi.Kota Batam memiliki peraturan mengenai pertanahan yang memiliki karakteristik berbeda dengan kota lain di Indonesia, Mayoritas daerahdaerah di Indonesia memiliki satu badan yang mengatur pertanahan yaitu dikenal dengan Badan Pertanahan Nasional, (selanjutnya disebut BPN) sedangkan Kota Batam memiliki dua badan sekaligus yang mengatur pertanahan Kota Batam yaitu Badan Pengusahaan yang namanya telah dirubah dua kali sebelum menjadi Badan Pengusahaan yaitu dari Otorita Batam, menjadi Badan Pengelolaan dan terakhir disebut sebagai Badan Pengusahaan (selanjutnya disebut BP Batam) dan BPN Kota Batam.

Batam menjadi salah satu daerah yang menggunakan HPL dibawah pengawasan BP Batam, seluruh hak atas tanah di kota Batam berada di bawah HPL yang diatur oleh BP Batam berdasarkan Kepres Nomor 41 Tahun 1973 yang 
menetapkan bahwa Batam ditetapkan sebagai Daerah dibawah pengawasan Otorita Batam yang sekarang dikenal sebagai BP Batam, sehingga tanah yang ada di Kota Batam seluruhnya merupakan milik BP Batam yaitu diletakkan diatas HPL BP Batam.

Berdasarkan Pasal 6 Permen Nomor 9 tahun 1965 mengatur kewenangan HPL yang berhak menerima Uang Wajib Tahunan ataupun ganti rugi, yang dimana BP Batam juga mengeluarkan peraturan bahwa HGB wajib membayar Uang Wajib Tahunan (selanjutnya disebut UWT) yang berjangka waktu selama 20 tahun sesuai Peraturan Kepala Badan Pengusahaan Batam Kawasan Perdagangan Bebas dan Pelabuhan Bebas Batam (Selanjutnya disebut Perka Bp Batam) Nomor 9 Tahun 2017 (selanjutnya disebut Perka Nomor 9 tahun 2017) Pasal 6 angka 2, Sehingga pemilik HGB diwajibkan untuk membayar UWT setiap 20 tahun sekali untuk memperpanjang masa kepemilikian HGB diatas HPL.

Hak Milik di Kota Batam juga berada diatas HPL, akan tetapi Hak Milik di Kota Batam tidak dikenakan UWT yang mana menjadikan hal tersebut tidak sesuai dengan Permen Nomor 9 tahun 1965 bahwa HPL berhak untuk mendapat Uang Wajib Tahunan atau ganti rugi. Namun jika dilihat arti sesungguhnya Hak Milik berdasarkan UUPA sangat tidak sesuai jika Hak Milik diletakkan diatas HPL karena UUPA menjelaskan bahwa Hak Milik merupakan Hak Atas Tanah yang tidak memiliki batas waktu tertentu, terkuat dan terpenuh. Maka berdasarkan Latar belakang permasalahan yang telah diuraikan diatas Penulis memiliki ketertarikan untuk membahas serta melakukan penelitian dan dituangkan kedalam bentuk artikel yang berjudul "Tinjauan Hukum mengenai Pengenaan Uang Wajib Tahunan terhadap Pemilik Sertipikat Hak Milik yang berada diatas Hak Pengelolaan di Kota Batam"

\section{B. Rumusan Masalah}

1. Bagaimanakah pengenaan Uang Wajib Tahunan terhadap Pemilik Sertipikat Hak Mili yang Berada diatas Hak Pengelolaan di Kota Batam dari aspek hukum?

\section{Metode Penelitian}

Jenis penelitian yang digunakan oleh Penulis adalah jenis penelitian hukum Normatif, karena Penulis meneliti yang terjadi di Kota Batam mengenai Hak atas tanah yaitu Hak milik yang diletakkan diatas HPL yang tidak sesuai dengan peraturan perundang undangan yang berlaku dimana sifat Hak milik adalah terkuat, terpenuh, turun temurun dan tidak memiliki jangka waktu. Kemudian BP Batam memegang hak pengelolaan yang diberikan oleh Presiden bahwa Bp Batam berhak untuk mendapat Uang ganti rugi berupa Uang Wajib Tahunan, Namun di Batam seluruh tanah berada diatas HPL dimana HGB wajib untuk membayar UWT sedangkan Hak Milik tidak membayar UWT sehingga tidak adanya kepastian Hukum mengenai Hak milik diatas HPL yang tidak ikut serta dalam membayar ganti rugi kepada pihak BP Batam. 
Teknik pengumpulan data yang dilakukan oleh Penulis adalah melalui pengumpulan data kepustakaan seperti Buku, Jurnal Hukum, Karya Ilmiah dan Kamus Hukum. serta wawancara dari para pihak yang berkaitan langsung dengan penelitian ini, sehingga semua data yang di peroleh berdasarkan hasil wawancara kepada BP Batam, BPN Kota Batam, PPAT, kemudian selain wawancara, penulis mengumpulkan data melalui observasi secara langsung mengenai Sertipikat Hak Milik yang berada di atas HPL, yang telah penulis lihat secara langsung di tempat kerja penulis.

Metode analisis data yang digunakan oleh Penulis adalah berupa metode penelitian kualitatif dimana menurut Sulistyo-Basuki Metode ini memiliki tujuan untuk memperoleh gambaran mengenai suatu hal berdasarkan pandangan manusia, kemudian menurut Putu Laksman Pendit, metode penelitian ini dirangcang untuk memberikan pengalaman melalui interaksi secara langsung antara peneliti dengan narasumber.

Penelitian ini memiliki sifat komparatif atau disebut juga perbandingan, maka dimaksudkan untuk membandingkan kondisi yang satu dengan kondisi lainnya di lain tempat, dan dapat disimpulkan kondisi mana yang terbaik.

\section{Hasil Penelitian dan Pembahasan}

Penulis melakukan wawancara yang pertama dengan BP Batam yaitu Bapak Jontara Siregar, S.H. Selaku Verifikator Dokumen Permohonan Perizinan Lahan, bahwa terbitnya sertipikat Hak Milik diatas HPL di Kota Batam berdasarkan pada Surat Rekomendasi yang dikeluarkan oleh BP Batam yang mengacu pada aturan yang dikeluarkan oleh Pemerintah yaitu Keputusan Menteri Negara Agraria/Kepala BPN Nomor 6 Tahun 1998 Tentang Pemberian Hak Milik atas Tanah Untuk Rumah Tinggal yaitu menjelaskan bahwa "Hak Guna Bangunan atau Hak Pakai atas tanah untuk rumah tinggal kepunyaan perseorangan warga negara Indonesia yang luasnya $600 \mathrm{M} 2$ atau kurang, atas permohonan yang bersangkutan dihapus dan diberikan kembali kepada bekas pemegang haknya dengan Hak Milik".

Berdasarkan Keputusan tersebut, BP Batam mengeluarkan Rekomendasi terbitnya sertipikat diatas Hak Pengelolaan yang akhirnya digunakan oleh BPN sebagai dasar penerbitan Sertipikat Hak Milik. Selain itu, terdapat juga wacana akan bubarnya BP Batam yang memperkuat keputusan untuk penerbitan sertipikat Hak Milik diatas Hak Pengelolaan tersebut.

Terbitnya sertipikat Hak Milik diatas HPL diperkirakan pada tahun 1998 hingga 2005 dan terdapat sekitar 15.000 sertipikat Hak Milik yang diterbitkan. Pemerintah pada saat itu memberlakukan Surat Keputusan Menteri Negara Agraria/Kepala BPN Nomor 6 Tahun 1998 yang seharusnya tidak berlaku untuk di Daerah Batam yang telah mendapatkan Hak Istimewa tersendiri dan di bawah wewenang BP Batam.

Sertipikat Hak Milik yang berada diatas HPL tidak dapat menghilangkan sifat asli dari Hak milik dikarenakan, Hak Milik merupakan Hak Atas Tanah yang 
tertinggi didalam peraturan Perundang-Undangan. Sehingga hak milik yang berada diatas HPL Kota Batam dapat dikatakan keliru dan tidak seharusnya diterbitkan karena jika diterbitkan akan tidak sesuai dengan pengertian serta sifat asli Hak Milik yang tercantum didalam UUPA.

Sertipikat Hak Milik jika diletakkan diatas HPL Kota Batam tidak dapat dikatakan illegal atau melanggar hukum yang berlaku karena sertipikat tersebut terbit didasarkan dari rekomendasi oleh BP Batam dan Rekomendasi tersebut terbit juga karena adanya Keputusan Menteri Negara Agraria/Kepala BPN Nomor 6 Tahun 1998. Sehingga BPN tidak salah untuk menerbitkan sertipikat Hak Milik berdasarkan dari Rekomendasi yang diterbitkan oleh BP Batam. Contoh rekomendasi tersebut akan menjadi lampiran dalam tulisan ini.

Masyarakat yang memiliki sertipikat Hak Milik tidak diwajibkan untuk membayar tarif UWT karena dapat dikatakan melanggar hukum sebab tidak sesuai dengan sifat asli Hak milik yang dituangkan dalam UUPA bahwa Hak Milik, terkuat, terpenuh, tidak memiliki jangka waktu, serta turun-temurun maka tidak boleh dan tidak akan dikenakan tarif UWT, jika pemilik Sertipikat Hak Milik ingin dikenakan tarif UWT maka Pemiliknya harus menandatangani suatu pernyataan diatas Materai bahwa bersedia untuk diturunkan menjadi HGB, jika telah ada pernyataan tersebut, BP Batam baru dapat melanjutkan proses turun Hak yaitu turunnya status hak milik menjadi HGB, jika tidak maka BP Batam tidak akan melanjutkan proses turun hak karena dengan adanya hal itu, BP Batam dapat di pidana atau dapat dikatakan melanggar hukum.

Pertanahan di Kota Batam melalui dua lembaga yaitu BP Batam dan BPN, Tahapan yang harus dilalui di BP Batam sebelum ke BPN adalah yang terakhir legalisasi, sehingga setelah itu, BPN menerbitkan Sertipikat berdasarkan Rekomendasi yang dikeluarkan oleh BP Batam. Dalam hal ini BPN dan BP Batam bertindak masing-masing serta tidak tunduk satu sama lain, hanya saja untuk penerbitan sertipikat BPN harus sesuai dengan Rekomendasi dari BP Batam selaku Pemegang HPL.

Izin Peralihan Hak yang terjadi terhadap sertipikat HGB, HGU dan Hak Pakai diwajibkan di Kota Batam karena tanah di Kota Batam yang seluruhnya berstatus diatas HPL, BP Batam pernah mengeluarkan Surat Pemberitahuan yang ditujukan kepada BPN Kota Batam yang berisikan bahwa dilakukannya penurunan Hak Milik menjadi HGB pada tanggal 19 Agustus 2019 akan tetapi tidak di laksanakan oleh Pihak BPN Kota Batam. Menurut BP Batam, untuk sertipikat Hak Milik yang ingin melakukan peralihan, lebih baik untuk melakukan IPH terlebih dahulu, hanya saja bersedia untuk menandatangani turunnya hak milik menjadi HGB, jika tidak bersedia maka tidak bisa dilakukan IPH tersebut. Di Kota Batam sudah ada beberapa pemilik sertipikat Hak Milik yang mengajukan langsung untuk menurunkan Hak nya menjadi HGB dikarenakan beberapa lembaga keuangan yang tidak bersedia untuk memberikan pinjaman kepada Pemilik Seripikat Hak Milik, Lembaga Keuangan tersebut hanya bersedia memberikan pinjaman kepada Pemilik SHGB sehingga, pemilik Sertipikat Hak Milik tersebut bersedia untuk menurunkan Hak milik tersebut menjadi HGB. Pewarisan tidak diharuskan untuk 
dilakukan IPH jika Sertipikatnya adalah Sertipikat Hak Milik, sehingga ketika ahli waris menerima hak tersebut, tetap berstatus Hak Milik berdasarkan Surat keterangan Waris.

BP Batam mengharapkan adanya satu Undang-Undang yang kuat mengenai turunnya Sertipikat Hak Milik karena menimbulkan ketidakpastian hukum terhadap masyarakat mengenai Sertipikat Hak Milik di kota Batam, karena sudah terjadi beberapa kasus mengenai pemilik sertipikat Hak Milik yang ingin melakukan pinjaman pada Bank akan tetapi Bank meminta Penetapan Lokasi atas Sertipikat Hak Milik yang mana, sertipikat Hak Milik tidak pernah mengenal adanya Penetapan Lokasi sehingga masyarakat memiliki ketidakpastian hukum atas sertipikat tersebut, maka dari itu, BP Batam mengharapkan terbentuknya suatu Undang-Undang yang kuat seperti Kepres mengenai permasalahan ini.

Wawancara yang kedua, dilakukan terhadap Bapak Irwan Toni, S.H. selaku Kepala Subseksi Pendaftaran Hak Atas Tanah bahwa hasil penelitian yang diperoleh adalah, Tanah HPL di Kota Batam tidak mengenal yang namanya Hak Milik, yang seharusnya terbit adalah Hak Milik di atas Tanah Negara bukan diatas tanah HPL, karena Hak Milik merupakan Hak Atas Tanah yang terkuat, dan tidak bisa di ganggu gugat. Batam memiliki sistem Lex Specialis Derogat Legi Generali, dimana hanya Pulau Batam yang diterapkan sistem seluruh tanah berada diatas HPL BP Batam, tidak seperti daerah lainnya yang ada di Indonesia, contohnya, di Jakarta memiliki HPL juga namun tidak secara keseluruhan, permohonan untuk adanya HPL juga harus melalui Sekretaris Negara seperti Tugu Monas yang ada di Jakarta.

Hak Milik di Kota Batam dapat terbit diatas HPL BP Batam karena adanya Rekomendasi yang dikeluakan oleh Pemimpin BP Batam terdahulu. Munculnya Rekomendasi terbitnya Hak Milik di atas HPL dikarenakan adanya kesalahan Penafsiran yang dilakukan oleh Pemimpin terdahulu sehingga terbit sekitar kurang lebih 15.000 sertipikat Hak Milik diatas HPL yang seharusnya tidak boleh dan tidak sewajarnya Hak Milik terbit diatas HPL BP Batam. BPN menerbitkan Sertipikat Hak Milik tersebut karena adanya Rekomendasi yang dikeluarkan oleh BP Batam pada saat itu. Penafsiran tersebut mengeluarkan kesimpulan bahwa tanah yang luasnya kurang dari $600 \mathrm{M}^{2}$, dapat diberikan status Hak Milik diatas HPL namun Penafsiran yang sesungguhnya adalah Hak Milik dapat diberikan diatas tanah Negara bukan diatas Tanah HPL.

Hak Milik yang berada diatas HPL tidak dapat menghilangkan sifat asli dari Hak Milik karena ada Undang-Undang yang mengkordinir secara keseluruhan, BP Batam didirikan berdasarkan Kepres, sedangkan Undang-Undang memiliki hierarki yang lebih tinggi dari pada Kepres, maka Kepres tidak dapan melanggar Undang-Undang tersebut. Kita sebagai Akademisi Hukum, sudah mengetahui adanya kecacatan hukum di Kota Batam ini mengenai terbitnya Sertipikat Hak Milik diatas HPL, namun dalam Pemerintahan, hal ini di anggap kesalahan Administrasi saja. Hak Milik diatas HPL ini tidak dapat dihapuskan serta tidak dapat diturunkan menjadi HGB dikarenakan akan mengakibatkan suatu gejolak di 
Masyarakat. Hal yang dapat dilakukan hanyalah Hak Milik tersebut keluar dari HPL sehingga Hak Milik tersebu tidak lagi berada diatas HPL.

Hak Milik yang terbit diatas HPL tidak dapat dikatakan melanggar hukum yang berlaku, hanya adanya kesalahan administrasi pemerintahan, sehingga tidak dapat diperkarakan. Karena apabila diperkarakan, masyarakat yang memiliki sertipikat Hak Milik akan melawan keras bahwasanya hal tersebut dapat merugikan mereka.

Pemilik sertipikat Hak Milik tidak diwajibkan serta tidak diperbolehkan untuk membayar UWT karena Hak Milik tetap menjadi Status yang kuat. Mereka tidak perlu membayar UWT yang perlu adalah Pemerintahan yaitu BPN Mencoret HPL yang tertera di dalam Sertipikat Hak Milik tersebut agar tercapainya Kepastian Hukum kepada Masyarakat terutama Pemilik Sertipikat Hak Milik tersebut.

BPN dan BP Batam merupakan Badan yang berbeda dan berdiri sendiri, BPN merupakan lembaga yang dikepalai oleh Menteri, serta berpedoman kepada UUPA dan Peraturan Menteri setingkatnya. Namun karena Batam memiliki kekhususan tersendiri mengenai pertanahan yang didasari oleh Kepres Nomor 41 Tahun 1973, maka izin untuk pendaftaran tanah harus melalui tahapan dari BP Batam terlebih dahulu, namun substansi dari pendaftaran tanah tetap berpedoman pada UUPA dan Menteri Setingkatnya.

Sertipikat Hak Milik yang ingin melakukan peralihan Hak tidak perlu dan tidak diwajibkan untuk melakukan IPH ke BP Batam, karena akan mengakibatkan turunnya Hak Milik menjadi HGB sehigga, jika pemilik sertipikat Hak Milik ingin melakukan Jual Beli dapat langsung melalui BPN, karena sesuai dengan sifat asli yang dimiliki Hak Milik yaitu terkuat, terpenuh, turun-temurun. Namun tetap ada beberapa masyarakat pemilik sertipikat Hak Milik yang mengajukan IPH ke BP Batam dan diterima oleh BP Batam karena adanya pernyataan tertulis serta bermaterai cukup dari Pemilik Sertipikat Hak Milik yang menyatakan bahwa kesediaan untuk diturunkan menjadi HGB, sehingga hal tersebut tidak dikatakan salah atau melanggar. BPN akan menerbitkan Sertipikat HGB yang baru sesuai dengan Rekomendasi yang terbit dari BP Batam.

BPN Kota Batam memiliki wacana mengenai ketidakpastian hukum terhadap status sertipikat Hak Milik yang berada di atas HPL yaitu dengan cara menghapuskan status HPL didalam Sertipikat Hak Milik, dengan seperti itu secara otomatis, Hak Milik tidak lagi berada didalam status HPL sehingga tidak ada lagi ketidak pastian hukum mengenai pengenaan Uang Wajib Tahunan terhadap Hak Milik yang berada diatas HPL tersebut.

Hasil dari wawancara terhadap Pejabat Pembuat Akta Tanah Ibu Maria Magdalena Ginting, S.H. mengenai tanggapan mereka tentang pernyataan BP Batam dan BPN adalah bahwa adanya sertipikat Hak Milik diatas HPL Kota Batam adalah mengakibatkan timbulnya ketidakpastian hukum, karena Hak Milik sudah jelas didalam UUPA adalah merupakan Hak Atas Tanah yang tertinggi sehingga tidak dapat diletakkan diatas Hak Milik apalagi dikenakan biaya UWT. Untuk kendala mengenai proses peralihan hak sertipikat Hak Milik itu ada, karena 
banyak masyarakat yang sudah lebih mengerti hukum dan tidak ingin dirugikan, sehingga masyarakat lebih memilih untuk tidak mengajukan IPH ke BP Batam dan langsung melalui BPN saja agar tidak terjadi penurunan Hak menjadi HGB. Pernah ada surat edaran mengenai proses dilakukannya IPH terhadap sertipikat Hak Milik hanya saja tidak dihiraukan dan tetap melewati proses secara langsung ke BPN. Masyarakat yang memiliki sertipikat Hak Milik belum pernah ada yang datang untuk meminta diturunkan Hak nya menjadi HGB, bahwa beliau setuju dengan Pihak BPN yang seharusnya HPL terhadap hak milik dihapuskan agar tidak ada lagi ketidakpasitian hukum yang terjadi.

Hasil Wawancara selanjutnya terhadap Pejabat Pembuat Akta Tanah Bapak Septa Suhendra, S.H., M.Kn. yaitu Beliau setuju mengenai pernyataan yang diberikan oleh BP Batam bahwa ketika pemilik sertipikat Hak Milik ingin melakukan peralihan hak, harus bersedia terlebih dahulu menandatangani sebuah pernyataan yang menyatakan bahwa ketika dilakukan IPH maka Hak Milik tersebut akan menjadi HGB, sehingga dapat dijalankan oleh pihak BP Batam, namun ketika masyarakat tersebut tidak setuju, maka tidak akan dilaksanakan oleh pihak BP Batam. Beliau setuju karena melalui proses yang benar, tidak sembarangan atau tidak memaksa masyarakat untuk langsung diturunkan hak nya, akan tetapi berdasarkan pada ketersediaan masyarakat itu sendiri, apakah bersedia atau tidak jika nantinya sertipikat hak milik tersebut akan berubah menjadi sertipikat HGB.

Bapak Septa juga setuju akan pernyataan BPN yaitu, akan dilakukan penghapusan terhadap HPL didalam sertipikat Hak Milik di Kota Batam. Pendapat Bapak Septa mengenai adanya sertipikat Hak Milik diatas HPL kota Batam adalah belum ada suatu ketentuan yang secara eksplisit mengatur mengenai pelarangan hak milik terbit diatas HPL, yang ada hanyalah pendapat-pendapat para ahli hukum yaitu berdasarkan dari keahlian mereka masing-masing, bahwa adanya hak milik diatas HPL bukanlah suatu yang Haram.

Pernah terbit suatu surat tidak resmi yang dikeluarkan oleh BP Batam agar dilakukannya penurunan Hak ketika adanya peralihan hak terhadap sertipikat Hak Milik, namun BPN tidak menjalankan ataupun mengindahkan surat tersebut. Bahwa pernah ada masyarakat yang datang kepada Bapak Septa untuk dilakukannya peralihan Hak terhadap Sertipikat Hak Milik dan atas hal tersebut, Bapak Septa selaku PPAT mengurus UWT kepada BP Batam agar dapat dilakukan peralihan hak berdasarkan surat yang diedarkan oleh BP Batam, namun saat sedang proses.

BPN memberi informasi bahwasanya tidak akan dilakukan penurunan hak seperti yang tertera dalam surat BP Batam sehingga dapat langsung melalui BPN jika ingin melakukan peralihan hak terhadap sertipikat Hak Milik, hingga saat ini. Berdasarkan penjelasan Bapak Septa, adanya surat rekomendasi yang dikeluarkan oleh Pemerintahan BP Batam pada tahun 1998 hingga 2005, terjadi karena adanya Surat Keputusan Menteri Negara Agraria/Kepala BPN Nomor 6 Tahun 1998 sehingga rekomendasi tersebut dapat dikeluarkan oleh BP Batam. 
Terbitnya sertipikat Hak Milik di Kota Batam tidak ada kesalahan, namun seharusnya HPL tersebut dihapuskan dulu sehingga menjadi tanah negara dan dapat diberikan Hak Milik. Menurut Bapak Septa, terbitnya sertipikat Hak Milik pada tahun 1998 hingga 2005 bisa jadi karena adanya unsur politik, seperti, untuk membuat masyarakat merasa adanya sesuatu hal yang menguntungkan yang diberikan oleh BP Batam kepada mereka. Namun hukum ini dinamis, ketika masyarakat membutuhkan, maka diberikan, hukum ini mengikuti masyarakat, sehingga ketika masyarakat sudah tidak lagi membutuhkan, maka hukum tersebut dikesampingkan kembali atau dihapuskan.

Terbitnya sertipikat Hak Milik diatas HPL ini hanyalah perlu dihapuskan masalah administratifnya, karena secara nyata di lapangan hak milik tersebut tetap memiliki sifat aslinya, sehingga hanya perlu dihapuskan secara administratif tulisan "diatas HPL Nomor.." kemudian saran yang dapat diberikan dari Bapak Septa mengenai permasalahan ini adalah sertipikat hak milik yang sudah terbit di Kota Batam tidak perlu dihapuskan, jangan sampai suatu saat menjadi hal melanggar Hak Asasi Manusia karena adanya kepentingan dari Pemerintahan itu sendiri.

Hasil Wawancara terhadap Pejabat Pembuat Akta Tanah Bapak Dr. Markus Gunawan, S.H., M.Kn. adalah bahwa adanya anutan sistem Domein Verklaring oleh BP Batam yang sesungguhnya sitem tersebut telah dihapus oleh UUPA karena adanya pertentangan dengan kesadaran hukum yang dimiliki Masyarakat Indonesia dan asas Negara yang telah merdeka serta modern. Negara seharusnya lebih tepat untuk ditempatkan sebagai organisasi kekuasaan dari seluruh rakyat dan bertindak selaku Badan Penguasa dari pada ditempatkan sebagai pemilik tanah.

Hak Pengelolaan lahan menurut Bapak Markus bukanlah merupakan Hak Atas Tanah, Negara memiliki Hak penguasaan atas tanah berdasarkan kewenangannnya yang bersifat publik serta perdata, sehingga kedudukan pemegang HPL sebagai Badan Penguasa bukanlah sebagai Pemilik. Dalam kapasitasnya sebagai Badan Penguasa, Pemegang HPL tidak dapat membatasi Hak-hak keperdataan yang dimiliki oleh Pemegang Hak Atas Tanah.

Kebijakan yang dilakukan oleh BP Batam sejak tahun 2008 untuk menghentikan rekomendasi pemberian Hak Milik atas tanah yang berada dibawah $600 \mathrm{M}^{2}$ dapat dipahami, namun kebijakan BP Batam mengenai perubahan Hak Milik menjadi HGB sangat memilukan serta memalukan karena secara paksa telah menghilangkan Hak Rakyat. Sesunguhnya, tidak ada satu Pasal perundang-undangan dibidang hukum pertanahan yang melarang untuk pemberian HPL terhadap Hak Milik. Jika BP Batam bersumber pada PP Nomor 40 Tahun 1996, maka hal tersebut sangat tidak tepat dikaenakan Peraturan tersebut mengatur mengenai HGB, HGU dan Hak Pakai, tidak ada mengatur mengenai Hak Milik dan HPL.

Terbitnya Sertipikat Hak Milik diatas HPL dapat dimaklumi karena tidak ada pelarangan. Namun untuk mencabut dan menggantikannya dengan HGB, 
selain menunjukkan tidak adanya kepastian hukum, keadilanm dan kemanfaatan Hukum, juga mencerminkan Domein Verklaring atau disebut juga bermentalkan penjajah.

Hasil penelitian selanjutnya terhadap Pejabat Pembuat Akta Tanah, Bapak Anly Cenggana, S.H. adalah bahwa, Hak milik lahir berdasarkan tanah Negara, tidak cocok untuk diletakkan diatas Tanah HPL karena tidak bisa dimiliki oleh pihak ketiga, apabila terjadi hak milik diatas HPL maka telah terjadi HPL bolong yang dimaksud adalah satu kesatuan berdasarkan pemberian atau pemanfaatan oleh Pemerintah Pusat, dengan adanya kebijakan penerbitan Hak Milik, sehingga HPL yang tadinya merupakan satu kesatuan menjadi bolong. Berdasarkan sisi Konstitusi hukum tidak memberikan kesempatan untuk Hak Milik berada diatas HPL, sehingga tidak seharusnya berdiri hak Milik diatas HPL.

Pengurusan peralihan Hak terhadap sertipikat Hak Milik diatas HPL belum pernah terjadi kendala karena BPN menyadari Hak Milik tersebut tidak dapat diturunkan menjadi HGB karena Hak Milik merupakan Hak yang tertinggi, terkuat dan terpenuh serta terbit berdasarkan Rekomendasi yang dikeluarkan oleh BP Batam.

Masyarakat yang memiliki sertipikat Hak Milik banyak yang datang untuk meminta kejelasan mengenai penurunan Sertipikat Hak Milik menjadi HGB, dan selaku pelayan masyarakat, Pejabat Pembuat Akta Tanah juga memiliki kewajiban untuk menjelaskan mengenai penurunan hak milik menjadi HGB tersebut bahwa belum adanya kewajiban serta kebijakan yang pasti untuk membayar UWT.

Bapak Anly memberi saran bahwa mengenai Sertipikat Hak Milik yang sudah terlanjur diterbitkan tidak dapat secara serta merta untuk di rubah menjadi HGB, maka tetap saja diberlakukan Hak Milik tersebut serta tidak perlu lagi untuk menerbitkan rekomendasi untuk penerbitan Sertipikat Hak Milik diatas HPL.

\section{Legalitas dari Sertipikat Hak Milik yang berada diatas Hak Pengelolaan}

Berdasarkan Teori yang dikemukakan oleh Gustav Radbruch mengenai Kepastian Hukum yang pertama adalah hukum itu bersifat positif yaitu peraturan Perungan-undangan yang harus di taati walaupun dianggap kurang adil. Bahwa didalam peraturan Perundang-undangan yaitu UUPA menjelaskan bahwa terdapat beberapa jenis Hak Atas Tanah yaitu salah satu nya adalah Hak Milik dimana Hak Milik merupakan jenis hak atas tanah tertinggi, terkuat dan turun temurun yang dalam arti bahwa tidak memiliki batasan waktu.

PP Nomor 40 Tahun 1996 menjelaskan bahwa yang dapat berdiri diatas HPL adalah HGB, HGU dan Hak Pakai, sedangkan Hak Milik tidak disebutkan dapat berdiri diatas HPL. Namun di Kota Batam telah terbit sekitar 15.000 Sertipikat Hak Milik yang memiliki status diatas HPL yang 
dimana seharusnya Hak Milik terbit diatas Tanah Negara. Sehingga pemberlakuan hukum harus bersifat positif sesuai dengan peraturan perundang-undangan yang ada belum tercapai dan tidak memenuhi teori kepastian hukum sebagaimana yang dikemukakan oleh Gustav Radbruch.

Syarat yang harus dipenuhi agar mencapai kepastian hukum yang kedua dan ketiga menurut Gustav Radbruch adalah harus berdasarkan fakta dan memiliki perumusan yang jelas untuk menghindari kekeliruan pada maknanya. Bahwa pada faktanya Sertipikat Hak Milik yang berada diatas HPL kota Batam terjadi karena adanya kesalahan yang dilakukan oleh Pemimpin BP Batam terdahulu, Kesalahan tersebut dapat dikatakan kesalahan dalam menafsirkan suatu Peraturan Perundang-Undangan, yaitu surat keputusan Menteri Negara Agraria/Kepala BPN Nomor 6 Tahun 1998.

Pada saat diterbitkan Sertipikat Hak Milik diatas HPL terdapat wacana BP Batam yang akan bubar sehingga menambah keyakinan untuk mengeluarkan Surat Rekomendasi untuk terbitnya Sertipikat Hak Milik diatas HPL, Surat Rekomendasi tersebut dilanjutkan oleh BPN sehingga BPN menerbitkan Sertipikat Hak Milik diatas HPL berdasarkan Rekomendasi tersebut.

Sertipikat Hak Milik yang telah terbit sekitar 15.000, dan hal ini tidak akan mungkin untuk dilakukan penurunan Hak menjadi HGB, karena yang nantinya akan menimbulkan keresahan pada masyarakat yang memiliki sertipikat Hak Milik dan akan berujung pada terjadinya demo ataupun kerusuhan yang akan dilakukan di Kantor BP Batam, hal ini berkaitan dengan teori kepastian hukum yang keempat menurut Gustav Radbruch bahwa hukum positif walaupun mudah untuk dilaksanakan namun tidak mudah untuk dirubah. Sehingga terbitnya Sertipikat Hak Milik diatas HPL tersebut bukanlah kesalahan masyarakat sehingga tidak boleh dilakukan penurunan Hak. Sehingga legalitas dari Hak Milik diatas HPL tetap memikiki kekuatan hukum sebagaimana yang tercantum dalam UUPA bahwa Hak Milik merupakan Hak tertinggi, terkuat dan turun-temurun.

BP Batam sebagai badan pengelolaan mengenai pertanahan di Kota Batam serta sebagai badan yang mengeluarkan rekomendasi agar BPN dapat menerbitkan sertipikat sesuai rekomendasi yang telah dikeluarkan BP Batam tersebut mengatakan bahwa legalitas yang dimiliki sertipikat Hak Milik diatas HPL tetap memiliki kekuatan hukum yang sesuai dengan UUPA sehingga tidak dapat di turunkan menjadi HGB tanpa persetujuan dari Pemilik sertipikat Hak Milik.

BP Batam dapat dikenakan pidana ataupun dapat dikatakan melakukan pelanggaran hukum karena telah menurunkan sertipikat Hak Milik yang telah diketahui bahwa Hak Milik merupakan Hak Atas Tanah tertinggi. Masyarakat yang memiliki sertipikat Hak Milik, kemudian ingin melakukan peralihan hak kepada orang lain, tidak perlu melakukan IPH 
terlebih dahulu seperti yang dilakukan oleh pemilik sertipikat HGB karena tidak ada kewajiban untuk melakukan hal tersebut, walaupun BP Batam pernah melakukan permohonan ke BPN dan mengeluarkan surat bahwa untuk peralihan sertipikat hak milik harus melakukan IPH terlebih dahulu sehingga akan terjadinya Penurunan Hak menjadi HGB, akan tetapi tidak pernah terjadi wacana tersebut, karena masyarakat yang memiliki sertipikat hak milik lebih memilih langsung untuk ke BPN agar tidak menjadi HGB.

BPN dalam menerima permohonan peralihan hak sertipikat hak milik, mereka tidak perlu meminta dilampirkannya IPH serta Faktur UWT walaupun didalam sertipikat tercantum tulisan diatas HPL, karena jelasnya legalitas dari Hak Milik itu sendiri. Dalam hal ini BPN tidak mengikuti permohonan dari BP Batam bahwa ketika adanya peralihan hak sertipikat Hak Milik agar dilakukan IPH terlebih dahulu, karena BPN berpedoman pada Undang-Undang yang lebih tinggi yaitu UUPA.

Teori Kepastian Hukum menurut Gustav Radbruch sangat serasi untuk dikaitkan terhadap penelitian ini karena menimbulkan ketidakpastian hukum bagi masyarakat pemilik sertipikat Hak Milik serta lembaga keuangan karena Lembaga keuangan tidak memiliki keberanian untuk memberikan pinjaman berdasarkan objek jaminan Hak Milik yang tidak memiliki dokumen pelengkap lainnya seperti Penetapan Lokasi, maka dari itu demi tercapainya kepastian Hukum, BPN akan mengeluarkan suatu kebijakan bagi masyarakat pemilik sertipikat Hak Milik agar tidak ada lagi beda penafsiran sebagaimana judul penelitian ini bahwa apakah pemilik sertipikat hak milik yang berada diatas HPL diwajibkan untuk membayar UWT. Kebijakan tersebut berupa penghapusan HPL terhadap hak milik di Kota Batam. Sehingga tidak ada lagi tulisan HPL yang tercantum didalam sertipikat Hak Milik.

\section{Kewajiban mengenai Pembayaran Uang Wajib Tahunan terhadap Pemilik Sertipikat Hak Milik yang berada diatas Hak Pengelolaan}

Berdasarkan Teori yang dikemukakan oleh Gustav Radbruch mengenai Kepastian Hukum yang pertama adalah hukum itu bersifat positif yaitu peraturan Perungan-undangan yang harus di taati walaupun dianggap kurang adil. Bahwa didalam peraturan Perundang-undangan yaitu UUPA menjelaskan bahwa terdapat beberapa jenis Hak Atas Tanah yaitu salah satu nya adalah Hak Milik dimana Hak Milik merupakan jenis hak atas tanah tertinggi, terkuat dan turun temurun yang dalam arti bahwa tidak memiliki batasan waktu.

Berdasarkan Permen Nomor 9 Tahun 1965 dijelaskan bahwa Hak Atas Tanah yang berdiri diatas HPL wajib membayar Uang Wajib Tahunan, akan tetapi Sertipikat Hak Milik yang memiliki sifat asli terkuat tertinggi, tidak memiliki jangka waktu sangat tidak pantas untuk ikut dalam membayar Uang Wajib Tahunan. Sehingga hal ini sudah tidak memenuhi 
syarat kepastian hukum yang dikemukakan oleh Gustav Radbruch bahwa hukum harus bersifat Positif yang seharusnya berlaku sesuai Peraturan perundang-undangan yang telah ada yaitu UUPA.

Syarat yang harus dipenuhi agar mencapai kepastian hukum yang kedua dan ketiga menurut Gustav Radbruch adalah harus berdasarkan fakta dan memiliki perumusan yang jelas untuk menghindari kekeliruan pada maknanya. Bahwa Sertipikat Hak Milik yang berada diatas HPL kota Batam sesuai dengan Permen Nomor 9 Tahun 1965 harus dikenakan uang wajib tahunan, akan tetapi faktanya di Kota Batam, Sertipikat Hak Milik yang berada diatas HPL tidak dikenakan Uang Wajib Tahunan. Kota Batam tetap berdiri mengikuti UUPA khusus untuk sertipikat Hak Milik tidak boleh dikenakan uang wajib tahunan karena Hak Milik merupakan Hak atas tanah yang tidak memiliki jangka waktu.

Berdasarkan hak tersebut, kepastian hukum sangat tidak dimiliki oleh Sertipikat Hak Milik yang berada diatas HPL Kota Batam, dimana UUPA menjelaskan Hak Milik tidak memiliki jangka waktu sedangkan Permena Nomor 9 Tahun 1965, HPL berhak menerima Uang Wajib Tahunan. Dan fakta yang diterapkan dikota Batam Sertipikat Hak Milik tersebut sangat jelas berada diatas HPL namun tidak dikenakan Uang Wajib Tahunan. Berdasarkan fakta tersebut, belum diterapkan suatu perumusan yang jelas untuk menghindari kekeliruan atas sertipikat Hak Milik yang berada diatas HPL tersebut.

Terbitnya sertipikat tersebut didasarkan pada rekomendasi yang dikeluarkan oleh BP Batam pada tahun 1998 sampai tahun 2005, namun sertipikat hak milik tersebut tidak pernah dikenakan biaya Uang Wajib Tahunan walaupun berada diatas HPL yang memiliki hak untuk menerima Uang Wajib Tahunan.

Hasil penelitian bahwa terbitnya Sertipikat Hak Milik berada diatas HPL merupakan suatu kekeliruan sehingga tidak dapat menghilangkan sifat asli dari hak milik yang merupakan hak atas tanah terkuat, terpenuh tidak memiliki jangka waktu. Karena hal tersebut, sertipikat hak milik tidak boleh dikenakan tariff UWT yang dapat dikatakan illegal atau melanggar hukum.

Pemilik sertipikat hak milik yang ingin membayar UWT harus bersedia untuk membuat pernyataan bahwasanya ia setuju akan dilakukan penurunan hak milik menjadi HGB yang bersifat tertulis dan ditandatangani diatas materai. Setelah ia setuju dan bersedia maka BP Batam akan melanjutkan proses penurunan hak tersebut dan mengeluarkan rekomendasi untuk penerbitan SHGB Ke BPN kota Batam.

Terdapat beberapa contoh bahwa hal ini tidak memenuhi syarat kepastian hukum yang keempat menurut Gustav Radbruch yaitu hukum mudah untuk dilaksanakan namun sulit untuk dilakukan perubahan dimana pemilik sertipikat Hak Milik mengalami hambatan untuk melakukan pinjaman pada lembaga keuangan dikarenakan sertipikat hak atas tanahnya 
yang berstatus hak milik. Lembaga keuangan tersebut meminta untuk dilampirkan Gambar Penetapan Lokasi, sedangkan Sertipikat Hak Milik tidak mengenal adanya Gambar Penetapan Lokasi, Gambar Penetapan Lokasi hanya terbit untuk pemilik sertipikat HGB, HGU, dan Hak Pakai.

Penulis ingin memberikan contoh lainnya yaitu masyarakat yang memiliki rumah berstatus Hak Milik ingin mendirikan bangunannya menjadi bertingkat, namun harus diterbitkan Izin mendirikan Bangunan terlebih dahulu, jika Izin mendirikan bangunan telah terbit, bangunan tersebut baru dapat di proses. Untuk menerbitkan Izin mendirikan bangunan diperlukan Gambar Penetapan Lokasi yang hanya dimiliki oleh HGB, HGU, Hak Pakai. Dalam hal ini, tidak sedikit masyarakat pemilik sertipikat hak milik mengalami kesulitan dengan adanya status hak milik diatas HPL, namun untuk dilakukan perubahan secara keseluruhan mengenai penurunan menjadi HGB belum tentu seluruh masyarakat setuju dan jika tidak diturunkan BP Batam merasa dirugikan karena tidak menerima Uang Wajib Tahunan.

Teori Kepastian Hukum yang dikemukakan oleh Gustav Radbruch melekat dalam pembahasan ini dimana, jikalau Sertipikat Hak Milik dikenakan UWT maka sangat bertentangan dengan sifat asli yang dimiliki oleh Hak Milik sehingga pemberlakuan untuk mencoret tulisan "diatas HPL" dalam sertipikat Hak Milik akan segera dilakukan sehingga tidak menimbulkan ketidak pastian hukum dalam masyarakat yang masih bingung mengenai Sertipikat Hak Milik yang berada diatas HPL apakah diwajibkan untuk membayar UWT atau tidak. Pada faktanya dilapangan sebenarnya tidak dipungut UWT untuk pemilik Sertipikat Hak Milik, akan tetapi lembaga keuangan memiliki keraguan untuk memberikan pinjaman kepada masyarakat yang menjaminkan sertipikat Hak Milik. Sehingga dengan adanya penghapusan tulisan bahwa Sertipikat Hak Milik berada diatas HPL maka akan memperkuat kepastian hukum bagi masyarakat dan lembaga keuangan.

\section{E. Kesimpulan}

Sertipikat Hak Milik yang berada diatas HPL BP Batam masih memiliki pengertian serta sifat-sifat yang tercantum di dalam UUPA bahwa hak milik adalah hak atas tanah yang terkuat, terpenuh serta turun-temurun. Bahwa sertipikat Hak Milik yang berada diatas HPL BP Batam terbit berdasarkan adanya rekomendasi yang dikeluarkan oleh Pemimpin BP Batam terdahulu, rekomendasi tersebut terbit diakibatkan adanya kesalahan penafsiran Peraturan PerundangUndangan yaitu surat keputusan Menteri Negara Agraria/Kepala BPN Nomor 6 Tahun 1998, yang berlaku Nasional dan seharusnya tidak untuk di Pulau Batam yang memiliki HPL. Sertipikat Hak Milik diatas HPL BP Batam yang terbit dari tahun 1998 hingga 2005 mencapai kurang lebih 15.000 sertipikat. BPN memiliki wacana untuk menghapus atau mencoret tulisan "diatas HPL, Nomor..." di dalam 
sertipikat Hak Milik, sehingga secara otomatis Sertipikat Hak Milik tidak lagi berada diatas HPL.

Sertipikat Hak Milik diatas HPL BP Batam tidak diwajibkan untuk membayar Uang Wajib Tahunan dan akan dikenakan pidana ataupun dianggap melanggar hukum jika tetap terjadi namun jika ada Pemilik Sertipikat Hak Milik diatas HPL yang ingin melakukan peralihan hak seperti balik nama sertipikat, mereka tidak diwajibkan untuk melakukan Izin Peralihan Hak di BP Batam, walaupun telah diterbitkan surat pemberitahuan mengenai terjadinya penurunan hak milik menjadi HGB. Pemilik sertipikat Hak Milik yang ingin memiliki Penetapan Lokasi demi kepentingan pinjaman kepada Lembaga Keuangan, harus bersedia untuk menandatangani pernyataan tertulis dan bermaterai cukup yang berisikan bahwa pemilik sertipikat setuju bahwasanya sertipikat hak milik akan diturunkan menjadi HGB, jika tidak setuju maka BP Batam tidak akan melanjutkan proses tersebut.

\section{Daftar Pustaka}

\section{Buku}

Amal, Bakhrul. (2017) Hukum Tanah Nasional. Jakarta : Thafa Media Yogyakarta,

Harsono, Boedi. (2016) Hukum Agrian Indonesia, Sejarah Pembentukan UndangUndang Pokok Agraria Isi dan Pelaksanaannya. Jakarta : Universitas Trisakti,

Limbong, Bernard. (2012) Hukum Agraria Nasional. Jakarta : Pustaka Margaretha

Mahfud, Muhammad. Hak Atas Tanah. Jakarta : Prestasi Pustaka, 2015

Ranoemihardja, R. (1982) Antang. Perkembangan Hukum Agraria di Indonesia, Aspek-aspek Dalam Pelaksanaan UUPA dan Peraturan Perundangan Lainnya di Bidang Agraria di Indonesia. Bandung : Tarsito

Santoso, Urip. (2017) Hak Atas Tanah, Hak Pengelolaan, dan Hak Milik Atas Satuan Rumah Susun. Jakarta : PT. Kharisma Putra Utama

Silalahi, Uber. (2006) Metode Penelitian Sosial. Bandung : Unpar Press.

Suardi. (2005) Hukum Agraria, Jakarta : Badan Penertbit IBLM

Supriadi. (2015) Hukum Agraria, Jakarta : Sinar Grafika

Sutedi, Andrian. (2007) Peralihan Hak Atas Tanah Dan Pendaftarannya. Jakarta : Sinar Grafika

\section{Referensi dari Peraturan Perundang-Undangan}

Indonesia, Undang-Undang Peraturan Dasar Pokok-Pokok Agraria, UU No. 5 tahun 1960 
Indonesia, Peraturan Pemerintah, Hak Guna Usaha, Hak Guna Bangunan, Hak Pakai Atas Tanah, PP No. 40 tahun 1996

Indonesia, Peraturan Menteri Agraria, Pelaksanaan Konversi Hak Penguasaan atas Tanah Negara dan Ketentuan-Ketentuan Tentang Kebijaksanaan Selanjutnya, Permenag No. 9 tahun 1965

Indonesia, Peraturan Presiden, Badan Pertanahan Nasional, Perpres Nomor 20 tahun 2015

\section{Referensi dari internet}

https://bpbatam.go.id/pages/read/44-sejarah, diakses pada tanggal 11 Oktober $\underline{2019}$

https://www.kompasiana.com/didno76/5b5f1ff16ddcae480d691452/letak-danluas-indonesia, diakses pada tanggal 11 Oktober 2019

https://www.kompasiana.com/andriyana/59da2a12adbe2f18844fef72/berapajumlah-pulau-di-indonesia?page=all, diakses pada tanggal 11 Oktober 2019

https://www.liputan6.com/news/read/3865431/10-jenis-jenis-tanah-di-indonesiadan-persebarannya, diakses pada tanggal 11 Oktober 2019

https://www.jurnalhukum.com/tanah-hak-pengelolaan/. Diakses pada tanggal 11 Oktober 2019

https://www.zonareferensi.com/letak-astronomis-indonesia/, diakses pada tanggal 11 Oktober 2019 